\title{
Visualization of the exopolysaccharide bacterial capsule and its distribution in oceanic environments
}

\author{
Karen E. Stoderegger, Gerhard J. Herndl* \\ Department of Biological Oceanography, Netherlands Institute for Sea Research (NIOZ), PO Box 59, 1790 AB Den Burg, Texel, \\ The Netherlands
}

\begin{abstract}
In an attempt to visualize the polysaccharide capsule of bacterioplankton in a more economic way than transmission electron microscopy offers, we modified a light microscopy method. By using a negative staining technique, bacterial capsules $>150 \mathrm{~nm}$ in dimension can be enumerated. This method was used to determine the contribution of capsulated bacteria to the total bacterial community in 3 different water masses of the Faroe-Shetland Channel (North Atlantic), and the open and the coastal North Sea. The contribution of capsulated bacteria to the total bacterioplankton community, integrated over the water column, was $7 \%$ in the North Atlantic, and 17 and $27 \%$ in the open and the coastal North Sea, respectively. Generally, a strong decline with depth in the contribution of capsulated bacteria to the total number of bacteria was found for the water column of the North Atlantic. There, the contribution of capsulated bacteria decreased from about $30 \%$ at $10 \mathrm{~m}$ depth to $6 \%$ at $100 \mathrm{~m}$ depth and ranging from 0.4 to $4 \%$ between 100 and $1300 \mathrm{~m}$ depths.
\end{abstract}

KEY WORDS: Bacteria $\cdot$ Capsule $\cdot$ Polysaccharide

Resale or republication not permitted without written consent of the publisher

Bacterioplankton are the principal mediators of the transformation of dissolved organic carbon into biomass and carbon dioxide (Azam \& Cho 1987). Therefore, bacterioplankton play a central role in the food web of the world's oceans channeling a significant fraction of the phytoplankton production to the microbial food web. Bacterioplankton abundance and productivity remain fairly constant over a wide range of aquatic systems (Cole et al. 1988, Ducklow \& Carlson 1992). Apparently, bacterial respiration is even more constant than either abundance or production (White et al. 1991), resulting in increasing bacterial growth efficiencies from oligotrophic to eutrophic systems (Del Giorgio \& Cole 1998). These generalizations, however,

*Corresponding author. E-mail: herndl@nioz.nl have to be treated with caution since there are still basic methodological problems related to the determination of the number of bacteria actually active (Zweifel \& Hagström 1995). Also, there is a general scarcity of bacterioplankton respiration measurements especially in oligotrophic waters (Jahnke \& Craven 1995, Williams 1998).

Standard methods to enumerate bacteria do not discriminate between active and dormant or even 'ghost' cells, which lack DNA completely (Zweifel \& Hagström 1995, Choi et al. 1996, 1999, Vosjan \& van Noort 1998). On the basis of a variety of different methods to enumerate metabolically active bacteria such as microautoradiography, there is some general consensus that, at a given time, a large fraction (up to $80 \%$ ) of the bacterial community is inactive (Hoppe 1978, Tabor \& Neihof 1982, Grossmann 1994, Karner \& Fuhrman 1997).

Bacteria with an intact intracellular structure, and therefore potentially active bacteria, are surrounded by a capsular layer, while the vast majority of bacteria with a damaged intracellular structure lack such a capsule (Heissenberger et al. 1996). Thus, we tentatively assumed that metabolically active bacteria synthesize a capsular layer and that inactive bacteria rapidly release the capsule. Laboratory experiments indicated that active bacteria are constantly renewing their capsular envelope and releasing a significant fraction of the polysaccharidic layer into the ambient water (Stoderegger \& Herndl 1998). These capsule-derived polysaccharides released into the ambient water were found to be remarkably resistant to further bacterial utilization (Stoderegger \& Herndl 1998).

In this report we describe an economic way to visualize capsule-bearing bacterioplankton using light microscopy in order to avoid the time-consuming transmission electron microscopy (TEM) approach used 
in a previous study (Heissenberger et al. 1996). Using this new method, we determined the contribution of capsule-bearing bacteria (hereafter the term 'capsulated bacteria' is used) to the total bacterial community in the water column of the North Atlantic and the North Sea.

Material and methods. Discrimination between capsulated and non-capsulated bacteria: To discriminate capsulated from non-capsulated bacterioplankton we modified the staining method of Plante \& Shriver (1998). Gelatin-coated slides were prepared by cleaning them overnight in a 70\% ethanol-1\% $\mathrm{HCl}$ solution and, after drying, dipping them into a warm $\left(60^{\circ} \mathrm{C}\right)$ solution of $0.1 \%$ gelatin and $0.01 \% \mathrm{CrK}\left(\mathrm{SO}_{4}\right)_{2} \times 12 \mathrm{H}_{2} \mathrm{O}$. The slides were stored frozen until use. The same volume of water was used for the enumeration of capsulated and non-capsulated bacteria as for the 4'-6diamidino-2-phenylindole (DAPI) or acridine orange counting of the total bacterial community. Each sample was fixed with $2 \%$ glutaraldehyde (final conc.) and filtered onto a $0.2 \mu \mathrm{m}$ polycarbonate filter (Poretics, $25 \mathrm{~mm}$ diameter), followed by rinsing with $0.5 \mathrm{ml}$ of $0.2 \mu \mathrm{m}$ filtered distilled water. The filter was then transferred upside-down onto a $10 \mu \mathrm{l}$ drop of distilled water placed on the gelatin-coated slide, instantly frozen in a horizontal position and stored at $-20^{\circ} \mathrm{C}$ until analysis (generally within $3 \mathrm{wk}$ after collecting the samples). Before enumeration, the filter was thawed and allowed to air-dry. After the filter was peeled off from the glass slide, the filter area was covered by a thin layer of $0.2 \mu \mathrm{m}$ filtered $0.25 \%$ Congo red (3 to 5 drops). Thereafter, the slide was allowed to dry at room temperature before it was flooded with 3 to 4 drops of Maneval's stain (Carolina Biological Supply Company, NC) for about 1 min. After careful rinsing with distilled water, the slide was gently blotted dry and examined under a phase contrast microscope (Zeiss, Axioplan) to determine the number of capsulated and non-capsulated bacteria.

The transfer efficiency of bacteria from the filter onto the slide was determined by filtering $5 \mathrm{ml}$ of seawater onto a black polycarbonate filter (Millipore, $0.2 \mu \mathrm{m}$ pore size, $25 \mathrm{~mm}$ filter diameter) after staining the bacteria with acridine orange. Subsequently, the bacteria were transferred onto a gelatin-coated slide as described above, and the number of bacteria counted on the slide was compared with the number of bacteria adhering to the filter. The transfer efficiency of bacteria from the filter to the slide was $92.8 \pm 4.3 \%$ $(\mathrm{n}=20)$.

All enumeration was done in duplicate and at least 300 bacteria per filter were counted. To avoid biases because of subjectivity, capsulated and non-capsulated bacteria were enumerated in samples of unknown origin to the examiner.
Sampling for enumeration of capsulated and noncapsulated bacterioplankton: During 2 cruises, one to the Faroe-Shetland Channel in the North Atlantic $\left(1^{\circ} \mathrm{W}, 62^{\circ} \mathrm{N}\right.$ to $6^{\circ} \mathrm{W}, 60^{\circ} \mathrm{N}$, RV 'Pelagia', July 1999$)$ and one in the North Sea $\left(2^{\circ} \mathrm{E}, 52^{\circ} \mathrm{N}\right.$ to $6^{\circ} \mathrm{E}, 54^{\circ} \mathrm{N}$, R/V 'Mitra', August to September 1999), water samples were taken during conductivity, temperature and depth profiler casts. Water was collected at selected stations and depths with 10-L NEOX bottles to determine the contribution of capsulated bacteria to the bacterioplankton community. Twenty $\mathrm{ml}$ water samples were fixed during the cruise in the North Atlantic and $5 \mathrm{ml}$ samples were fixed during the North Sea cruise, both with $2 \%$ glutaraldehyde (final conc.), and processed on board following the protocol for the negative staining technique to discriminate between capsulated and non-capsulated bacteria as described above.

Bacterial enumeration: Total bacterial abundance was determined in 1 to $5 \mathrm{ml}$ samples after staining the bacteria with acridine orange (Hobbie et al. 1977) or DAPI (Porter \& Feig 1980) and filtering them onto black polycarbonate filters (Millipore, $0.2 \mu \mathrm{m}$ pore size, $25 \mathrm{~mm}$ filter diameter). Bacteria were enumerated with an epifluorescence microscope (Zeiss Axioplan) at $1250 \times$ magnification. At least 300 bacteria were counted per sample.

Results. Evaluation of the method used to discriminate capsulated from non-capsulated bacteria: The applied staining technique is basically a combined structural staining method, where the bacterial cell is stained with a basic dye and the background with an acidic dye, leaving the capsular envelope unstained. This negative staining technique allowed us to distinguish between capsulated and non-capsulated bacteria if the capsules are at least $150 \mathrm{~nm}$ in width. Fig. 1 shows representative images using this negative staining technique. The capsules are clearly visible as a white (unstained) halo around the bacterial cell. In seawater cultures, bacteria are usually larger, with a higher proportion of capsulated bacteria (Fig. 1a) than in natural waters (Fig. 1b). However, no relation was found between the size of bacteria and the presence of a capsule for natural bacterioplankton (data not shown). Even very small bacteria are able to develop a capsule large enough to be visualized using light microscopy (Fig. 1b).

Abundance of capsulated and non-capsulated bacteria in the water column of the North Atlantic and the North Sea: The contribution of capsulated bacteria to the total number of bacteria was determined in the North Atlantic, in the North Sea and at the southern entrance of North Sea water into the Dutch Wadden Sea (at the Netherlands Institute for Sea Research [NIOZ] pier) using the negative staining method. Averaging over the depth range of the water column 
Fig. 1. Visualization of the bacterioplankton capsule using the negative staining technique, Congo red and Maneval's stain. The dense capsule becomes visible as a white (unstained) halo around the stained bacterium. Black arrows indicate examples of capsulated bacteria, white arrows examples of non-capsulated bacteria. Typical examples are shown (a) for a nutrient-enriched seawater culture and (b) for the water column of the North Sea (sampling depth $20 \mathrm{~m}$ )
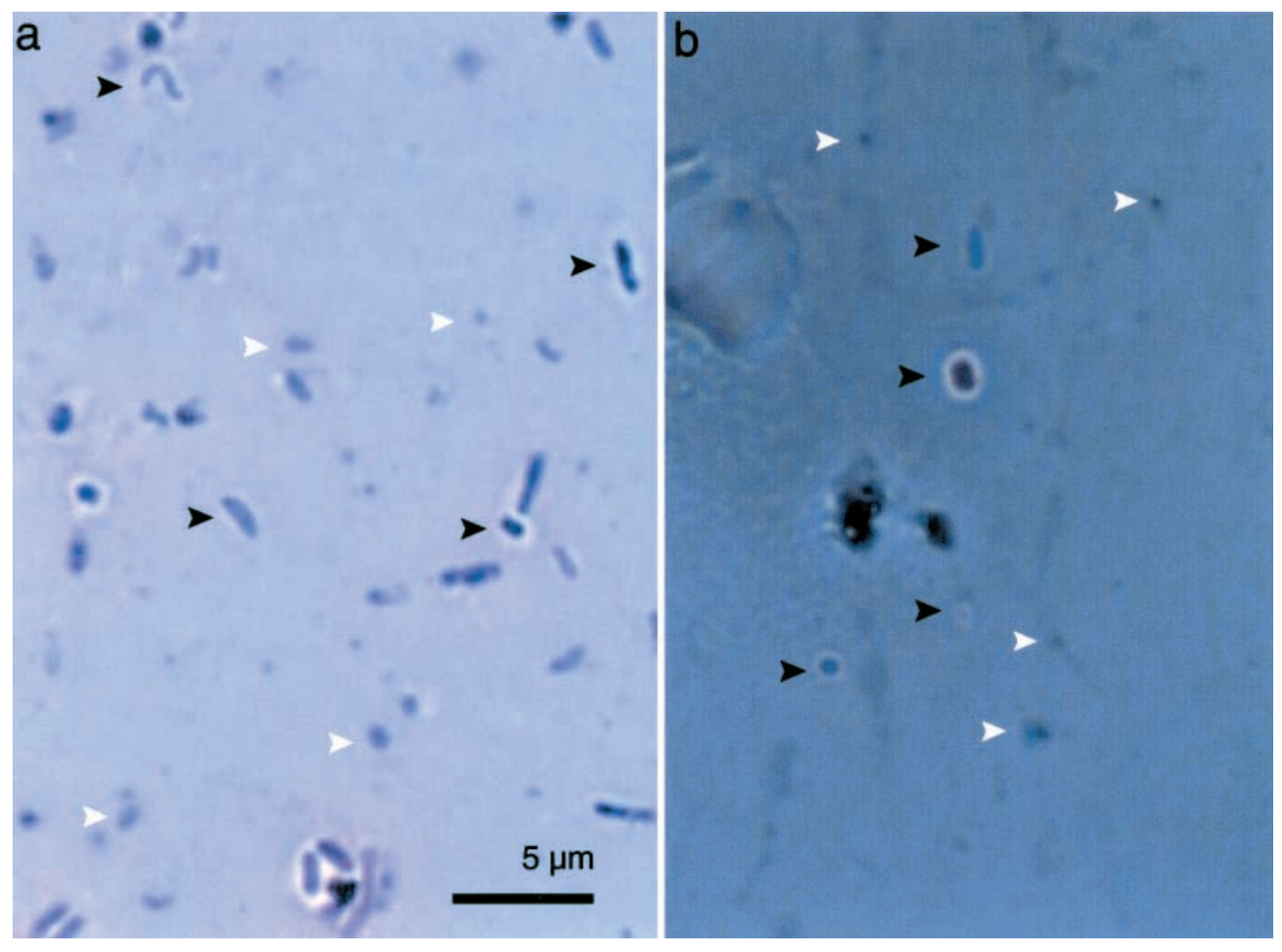

sampled at each site, about $7 \%$ of the bacterioplankton of the North Atlantic, $17 \%$ of the bacteria in the North Sea and $27 \%$ of the bacteria collected from the coastal North Sea off the NIOZ pier were capsulated (Table 1). No specific trends in the distribution of capsulated bacteria in the water column were detectable for the shallow North Sea (40 m depth at the open North Sea stations sampled, $<2 \mathrm{~m}$ at the coastal site). In contrast, a sharp decrease with depth in the contribution of capsulated bacteria to total bacterial abundance was detectable in the Faroe-Shetland Channel of the North Atlantic (Fig. 2). In the Faroe-Shetland Channel, we sampled oceanic and shelf waters and the frontal system between the oceanic and the shelf waters. In the euphotic zone, the contribution of capsulated bacteria

Table 1. Percentage of capsulated bacteria in different water masses averaged over several days and depth layers. Data are means \pm SD. Water masses differed significantly in the percentage of capsulated bacteria (Bonferroni $\mathrm{p}<0.001$ for all combinations). The depth range of samples collected was 10 to $1300 \mathrm{~m}$ for the North Atlantic, 10 to $45 \mathrm{~m}$ for the North Sea and 0.2 to $0.5 \mathrm{~m}$ for the Netherlands Institute for Sea Research (NIOZ) pier site

\begin{tabular}{|llcr|}
\hline Sample station (period) & Water type & $\begin{array}{r}\text { Capsulated } \\
\text { bacteria (\%) }\end{array}$ & $\begin{array}{r}\text { Number of } \\
\text { samples }\end{array}$ \\
\hline North Atlantic (July 99) & Oceanic $>100 \mathrm{~m}$ & $9.4 \pm 9.1$ & 51 \\
& Oceanic $<100 \mathrm{~m}$ & $2.5 \pm 1.9$ & 29 \\
North Sea (September 99) & Shelf & $17.2 \pm 9.2$ & 186 \\
NIOZ pier (June 99) & Coastal & $26.6 \pm 5.4$ & 25 \\
\hline
\end{tabular}

to total bacterial abundance was significantly higher than in the deeper layers of all areas sampled (Bonferroni $\mathrm{p}<0.001)$. Generally, the contribution of capsulated bacteria to the total bacterial abundance was significantly higher in oceanic waters than at the frontal stations (Wilcoxon $\mathrm{p}=0.0093, \mathrm{n}=11$ ). In oceanic waters, the mean contribution of capsulated bacteria to total bacterial abundance declined from $30 \pm 9 \%(n=3)$ at $10 \mathrm{~m}$ depth to $3 \pm 1.7(\mathrm{n}=2)$ at $150 \mathrm{~m}$ depth and varied between 0.4 and $4 \%$ from 150 to $1300 \mathrm{~m}$ depths (Fig. 2). At the frontal stations, capsulated bacteria contributed $15 \pm 12 \%$ to the total bacterial abundance at $10 \mathrm{~m}$ depth, declining to $2 \pm 0 \%(\mathrm{n}=2)$ at $40 \mathrm{~m}$ depth and ranged from 0.8 to $3 \%$ between 60 and $430 \mathrm{~m}$ depths. At the shelf stations, the mean contribution of capsulated bacteria was $10 \pm 7 \%(n=5)$ and $13 \pm 11 \%(\mathrm{n}=5)$ at 10 and $30 \mathrm{~m}$ depths, respectively, and declined with depth. At $200 \mathrm{~m}$ depth, $2 \%$ of the bacteria were capsulated (Fig. 2).

Discussion. Almost all intact or active bacterioplankton are surrounded by a more or less dense polysaccharide capsule fixed to the outer cell wall of bacteria that is constantly renewed (Heissenberger et al. 1996, Stoderegger \& Herndl 1998). In the present study, we adapted the negative staining method of Plante \& Shriver (1998) to distinguish between capsulated and 


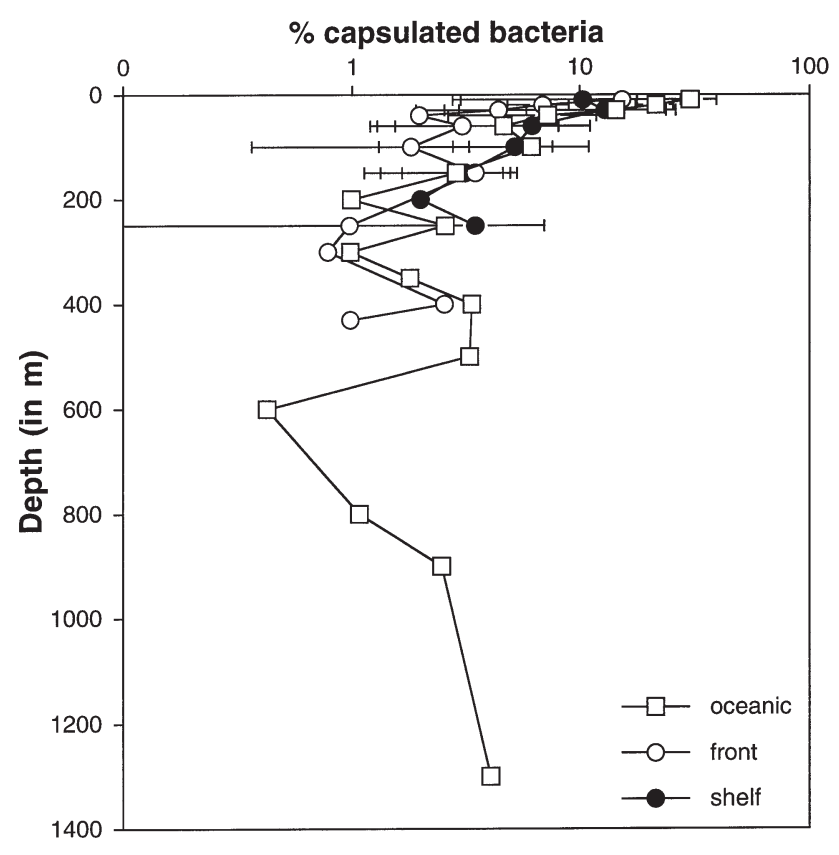

Fig. 2. Contribution of capsulated bacteria to total bacterial abundance in different water masses (oceanic, frontal system, shelf waters) in the Faroe-Shetland Channel (North Atlantic). Symbols represent means of duplicate determination per sample. Standard deviation is given when there were at least 2 samples per water mass

non-capsulated bacteria in natural water samples (Fig. 1).

The applied staining method is a combined method, where the positively and negatively charged parts are stained, leaving the more hydrophobic capsule unstained as a white halo around the bacterial cell. The bacterial capsule is known to consist of high molecular weight polysaccharides with either one hydrophobic region at one end of the polysaccharide molecule (amphiphilic polymer) or hydrophobic groups distributed across the entire molecule (polyphilic polymers) (Neu 1996). The bacterial amphiphiles are common in both Gram-negative and -positive bacteria. A typical example of an amphiphile for Gram-negative bacteria is the lipopolysaccharides (Neu 1996). The bacterial polyphilic polymers are polysaccharides containing either deoxy sugars or other hydrophobic components such as acyl, methyl or other groups. Probably the best known examples of bacterial polyphilic polysaccharides are the 6-deoxy sugars rhamnose and fucose, as well as $N$-acetyl-hexosamines (Neu 1996). However, other deoxy sugars might also be responsible for the hydrophobic character of the polysaccharide (Kenne \& Lindberg 1983).

Bayer \& Bayer (1981), however, reported that the bacterial capsule of Escherichia coli is highly negatively charged. A hydrophilic bacterial capsule that is negatively charged would probably be stained with the Maneval's stain and would therefore remain invisible. It seems likely that the bacterial capsule consists of both hydrophobic and hydrophilic regions, allowing therefore the visualization of the capsule.

A major advantage of this light microscopy method over the previously used TEM technique (Heissenberger et al. 1996) is the comparatively fast and easy sample preparation allowing a more economic sample processing. The main disadvantage of this light microscopy method over the TEM technique is its lower resolution. A very thin or only partially developed capsular layer may not be detectable by light microscopy. Because of the lower resolution of the light microscopy technique, the term 'capsulated bacteria' used in this paper represents the 'extensive capsule' and the 'welldefined capsule' categories described by Heissenberger et al. (1996) using TEM. Because of these methodological constraints, our estimates of the contribution of capsulated bacteria to the total bacterial abundance have to be considered as conservative estimates.

In this study, a higher percentage of capsulated bacteria was found in areas with generally higher nutrient concentrations. An overall increase in the contribution of capsulated bacteria to total bacterial abundance was found from the North Atlantic waters (7\% capsulated bacteria) to the coastal North Sea waters (27\% capsulated bacteria) (Table 1). In a previous study using TEM to enumerate capsulated bacteria from the meso-

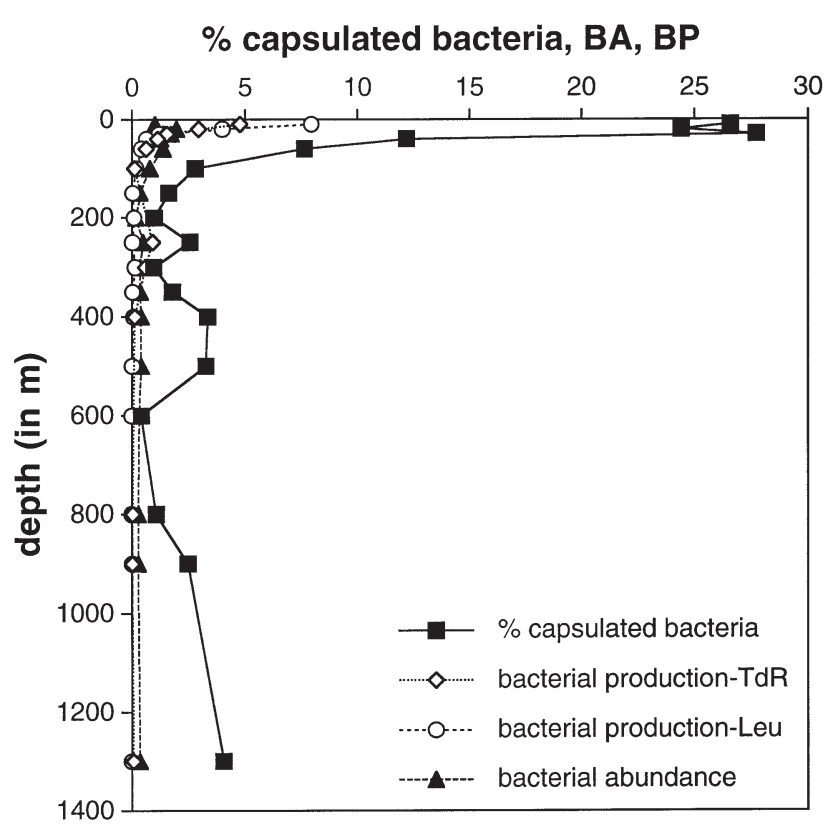

Fig. 3. Typical depth profile of the percentage of capsulated bacteria, bacterial abundance $\left(\mathrm{BA}, \times 10^{6} \mathrm{ml}^{-1}\right)$ and bacterial production (BP) measured by thymidine (TdR) and leucine (Leu) incorporation $\left(\mu \mathrm{g} \mathrm{C} \mathrm{l}^{-1} \mathrm{~d}^{-1}\right)$ in the water column of the North Atlantic 
to oligotrophic northern Adriatic Sea, the percentage of capsulated bacteria ranged between 20 and $25 \%$ of the total bacterial community present (Heissenberger et al. 1996), which is within the range reported here. Cowen (1992) found that, on average, $10 \%$ of deep-sea bacterioplankton in the vicinity of a hydrothermal vent were capsulated as compared with $80 \%$ capsulated bacteria associated with deep-sea marine snow. The sharp decrease with depth in the contribution of capsulated bacteria to total bacterial abundance as detected in the water column of the North Atlantic corresponds to the depth profiles obtained for bacterial abundance, and thymidine and leucine incorporation at these stations (Herndl unpubl. data, van Noort unpubl. data). A typical example of such a depth profile is shown in Fig. 3. This indicates that the percentage of capsulated bacteria is related to the overall bacterial activity.

In summary, the method described in this paper is suitable for the enumeratation of the abundance of capsulated bacteria even in the mesopelagic zone. Thus, we have a tool available now to economically enumerate capsulated bacterioplankton and to address questions concerning the ecological role of exopolysaccharidic capsules of bacterioplankton in the oceanic realm.

Acknowledgements. Financial support was provided by a grant from the EU-TMR (MAS3-CT97-5046) to K.E.S. Shiptime was provided by the NIOZ (for the BIO-PROCS cruise) and by the National Institute for Coastal and Marine Management (RIKZ; Mitra cruise). The support of the ships' crews during work at sea is gratefully acknowledged. This work is in partial fulfillment of the requirements for a $\mathrm{PhD}$ degree from the University of Vienna by K.E.S. This is publication no. 3647 of the NIOZ.

\section{LITERATURE CITED}

Azam F, Cho BC (1987) Bacterial utilization of organic matter in the sea. In: Fletcher $M$ (ed) Ecology of microbial communities. Cambridge University Press, Cambridge, p 261-281

Bayer ME, Bayer MH (1981) Fast response of bacterial membranes to virus adsorption: a fluorescence study. Proc Natl Acad Sci USA 78:5618-5622

Choi JW, Sherr EB, Sherr BF (1996) Relation between presence-absence of a visible nucleoid and metabolic activity in bacterioplankton cells. Limnol Oceanogr 41:1161-1168

Choi JW, Sherr BF, Sherr EB (1999) Dead or alive? A large fraction of ETS-inactive marine bacterioplankton cells, assessed by reduction of CTC, can become ETS-active with incubation and substrate addition. Aquat Microb Ecol 18:105-115

Editorial responsibility: John Dolan,

Villefranche-sur-Mer, France
Cole JJ, Findlay S, Pace ML (1988) Bacterial production in fresh and saltwater ecosystems: a cross-system overview. Mar Ecol Prog Ser 43:1-10

Cowen JP (1992) Morphological study of marine bacterial capsules: implications for marine aggregates. Mar Biol 114: 85-95

Del Giorgio PA, Cole JJ (1998) Bacterial growth yield efficiency in natural aquatic systems. Annu Rev Ecol Syst 29: 503-541

Ducklow HW, Carlson CA (1992) Oceanic bacterial production. Adv Microb Ecol 12:113-181

Grossmann S (1994) Bacterial activity in sea ice and open water of the Weddell Sea, Anarctica: a microautoradiographic study. Microb Ecol 28:1-18

Heissenberger A, Leppard GG, Herndl GJ (1996). Relationship between the intracellular integrity and the morphology of the capsular envelope in attached and free-living marine bacteria. Appl Environ Microbiol 62:4521-4528

Hobbie JE, Daley RJ, Jasper S (1977) Use of Nuclepore filters for counting bacteria by epifluorescence microscopy. Appl Environ Microbiol 33:1225-1228

Hoppe HG (1978) Relations between active bacteria and heterotrophic potential in the sea. Neth J Sea Res 13:78-98

Jahnke RA, Craven DB (1995) Quantifying the role of heterotrophic bacteria in the carbon cycle: a need for respiration rate measurements. Limnol Oceanogr 40:436-441

Karner M, Fuhrman JA (1997) Determination of active marine bacterioplankton: a comparison of universal 16S rRNA probes, autoradiography, and nucleoid staining. Appl Environ Microbiol 63:1208-1213

Kenne L, Lindberg B (1983) Bacterial polysaccharides. In: Aspinall GO (ed) The polysaccharides. Academic Press, New York, p 287-363

Neu TR (1996) Significance of bacterial surface-active compounds in interaction of bacteria with interfaces. Microb Rev 60:151-166

Plante CJ, Shriver AG (1998) Differential lysis of sedimentary bacteria by Arenicola marina L.: examination of cell wall structure and exopolymeric capsules as correlates. J Exp Mar Biol Ecol 229:35-52

Porter KG, Feig YS (1980) The use of DAPI for identifying and counting aquatic microflora. Limnol Oceanogr 25:943-948

Stoderegger K, Herndl GJ (1998) Production and release of bacterial capsular material and its subsequent utilization by marine bacterioplankton. Limnol Oceanogr 43:877-884

Tabor PS, Neihof RA (1982) Improved method for determination of respiring individual microorganisms in natural waters. Appl Environ Microbiol 43:1249-1255

Vosjan JH, van Noort GJ (1998) Enumerating nucleoid-visible marine bacterioplankton: bacterial abundance determined after storage of formalin fixed samples agrees with isopropanol rinsing method. Aquat Microb Ecol 14:149-154

White PA, Kalff J, Rasmussen J, Gasol JB (1991) The effect of temperature and algal biomass on bacteial production and specific growth rate in freshwater and marine habitats. Microb Ecol 21:99-118

Williams PJIB (1998) The balance between plankton respiration and photosynthesis in the open oceans. Nature 394: $55-57$

Zweifel UL, Hagström $\AA$ (1995) Total counts of marine bacteria include a large fraction of non-nucleoid-containing bacteria (ghosts). Appl Environ Microbiol 61:2180-2185

Submitted: April 24, 2001; Accepted: July 26, 2001

Proofs received from author(s): November 1, 2001 